\title{
Human Rights and Economic Growth
}

\section{Aziz Siddiqui}

Is there a conflict between development on the one hand and democracy and/or human rights on the other? The issue began to be seriously examined some forty years ago ${ }^{1}$ and the controversy has simmered because there has been empirical evidence to indicate at least some shortterm validity to those who do see a conflict and press the primacy of growth. They take off from premises like Einstein's, "An empty stomach makes a poor political adviser."

The controversy in recent years has not so much been for and against human rights as over which category of it should have precedence: civil and political rights or economic, social and cultural rights. Originally, the bill of rights had remained confined only to the first category. But after World War II, when the newly formed United Nations began to consider the need for a universal declaration and, later, for a binding covenant on the subject, inclusion of economic, social and cultural rights was vehemently and successfully argued, especially by the socialist bloc of countries.

Later the issue even became an element in the cold war. While the West assumed the title of 'Free World' on the basis of its relative guarantees of civil and political rights, the East claimed credit for its primacy to economic rights. The developing countries too, unable or uninclined for various reasons and to varying degrees to accept international standards in guaranteeing the freedoms to their people, began when challenged to claim an overriding need to concentrate on the economic backwardness of their people.

To the extent of form the issue of precedence was sought to be resolved at the World Conference on Human Rights held in Vienna in 1993. The Declaration that was adopted at the end declared that all the categories of human rights were universal, indivisible and interdependent. ${ }^{2}$ None, therefore, could have precedence over, and demand a price from the others. It was however asked to be accepted that while the civil and political rights

\footnotetext{
${ }^{1}$ See for instance, Seymour Martin Lipset, Political Man: The Social Bases of Politics, 1959; and "Some Social Requisites of Democracy: Economic Development and political Legitmacy," in American Political Science Review, March 1959.

2 "All human rights are universal, indivisible and interdependent and interrelated. The international community must treat human rights globally in a fair and equal manner and on the same footing, and with the same emphasis..." Article 5, Vienna Declaration and Programme of Action, 1993.
} 
- freedom of the press, equality before the law, participation through elections, etc. - could be immediately guaranteed, the other rights - to education, health, etc. - needed time to be ensured.

In practice, however, the Declaration did not much change the situation on the ground. At the annual sessions of the Human Rights Commission in Geneva, when delegations of the European Union or the US raise issues of arbitrary detentions, excessive use of police force, extra judicial killing, press curbs etc., countries like Malaysia and even India plead special circumstances and even argue that those who have left them with a vast legacy of post colonial problems ought to know better. ${ }^{3}$

There is yet another caveat strongly made. It is that the western emphasis on the right of the individual that has come to characterise the UN standards is incompatible with other cultures. The Africans, for instance, have argued that their traditions place tribal and group interests above the individual; even that the individual barely has an identity in terms of rights except as a member of the group, animated by a spirit of solidarity. This is said to contrast with the atomistic view of the Western world which regards individuals as locked in a constant struggle against society for the redemption of their rights. Indeed, the regional convention by the Organisation of African Unity is called 'African Charter of Human and Peoples' Rights'.

There has also been the advocacy of a separate 'Asian way'. The plea has been that Asians place greater value on prevalence of harmony in the community than on individual rights; that the Confucian-based cultural values of East Asia stress the importance of family and society and mandate consensus-oriented politics. "The expansion of the rights of the individual to behave or misbehave as he pleases has come at the expense of orderly society," said Singapore's Lee Kuan Yew, the leading exponent of this Asian Way.

\footnotetext{
${ }^{3}$ For instance, at the 1997 Human Rights Commission session at Geneva, thus the Malaysian delegate: "There is selective use of human rights by some nations as political weapons against their adversaries. The North manifests an attitude of total conceit in castigating countries for being slow in effecting reforms. To allow oneself to be lectured and hectored on freedom and human rights after years of struggle to regain one's liberty and human dignity by those who participated in and benefited from the subjugation is to suffer impudence.." etc. Or thus the Indian representative, "The commission seems to have adopted an approach that is both adversarial and selective. It has recently heard a call to monitor, report and expose human rights violations with a view to putting pressure on government and marshalling international condemnation and public embarrassment against those governments. This approach leads to anger and acrimony..."
} 
Cultural relativism is also pressed in relations to Islamic countries. Islam, it is said, offers its own charter of rights, and this cannot be allowed to be superseded by any other norms. Conflict is seen most strikingly to occur in the areas of women's rights, freedom of worship and conscience, and judicial punishments. ${ }^{4}$

The view mostly pressed on behalf of the developing world has therefore been that it should be for individual states to interpret international human rights standards in accordance with their history, culture, political system and level of economic development. It is notable that the de-emphasising of civil and political rights in particular has often come from the governments in power. It is rarely shared by the opposition, and the various sections of civil society in the same countries. When it has also been accompanied by advance in the other sector it seemed to have good reason to be self-righteous. Autocratic governments did, in some instances, seem to have improved the life of the people in the material sense.

Singapore, for instance, was not much more than a squalid backwater at independence in 1959, and had not changed much when it joined and then broke away from Malaysia in 1965. But after that its fortunes saw rapid transformation. By 1990 it had become one of Asia's Little Dragons reaching levels of per capita income comparable with the West: ahead in fact even of UK on the basis of purchasing price parity.

Other so-called Asian Tigers, Taiwan, South Korea and Hong Kong, rose equally rapidly to similar heights and under similar conditions of authoritarian rule. Indonesia engineered its 'economic miracle', with GDP growth ranging from over 6 per cent to close to 8 per cent in some years, under barely disguised dictatorship. And Malaysia's authoritarianism might have been 'soft' but it was as unmistakable as its economic advance was emphatic.

South Korea mostly performed best in its most repressive years: it had a GDP growth rate of 9.5 per cent in the period from 1965 to 1980, of 8.6 per cent from 1980 to 1987 , of 12 per cent in 1987 and 1988, 9.6 per cent in 1990 and 9.1 per cent in 1991. Later as repression began to unwind

\footnotetext{
${ }^{4}$ The differences of cultural and historical experiences causing variations of emphasis on the interpretation of human rights - cultural relativism, in short - had to be conceded at the World Conference on Human Rights at Vienna in 1993. Article 5 of its Declaration said in part: "While the significance of national and regional peculiarities and various historical, cultural and religious backgrounds must be borne in mind, it is the duty of states, regardless of their political, economic and cultural systems, to protect and promote all human rights and fundamental freedoms."
} 
growth also declined to the more normal 5 per cent, give or take a percentage point.

China, despite its extraordinary size, has sustained an average of 9 per cent growth over the past two decades, reaching even up to 13.4 per cent in 1993. Another two decades of such growth and its GNP will be one and a half times that of the US.

In Latin America too, the economies of Chile and Peru virtually collapsed under democratic rule, but saw a dramatic turnaround under authoritarian governments. President Alberto Fujimori was democratically elected, but he promptly proceeded to suspend the Peruvian constitution and rewrite one of his own giving him almost unrestrained powers. He then created an economic transformation.

The countries of East Asia are indeed a notable example of the sacrificing of personal freedom and political participation for booming economies. The parliament in Singapore has mostly had a solitary opposition member, and he too has been pursued through courts to almost a point of financial ruin. Other dissenters too are promptly and effectively disciplined. Malaysia allows opposition groups to function but there are almost insuperable barriers against their coming into power. Within the ruling party, emerging challenges have received short shrift. In South Korea, although political arrests, torture and summary execution of the Park Chung $\mathrm{He}$ and Chun Doo Hwan years lie in the past following the students movement of the late $80 \mathrm{~s}$, restraints on freedoms still continue. And in Indonesia the current rampancy of popular unrest is a consequence of over thirty years of President Suharto's so-called New Order. The groups allowed to function in the parliament besides the ruling Golkar could not even call themselves an opposition, and they had never initiated or blocked a single piece of legislation in all the years of their life. Press curbs, including closure of papers and expulsion of foreign journalists, have been a part of governance in these countries.

So where does that leave the debate about human rights and economic development?

The latter does often require hard decisions to be made, more so if the pace is desired to be quickened. Authoritarianism tends to be a help insofar as it concentrates all decision-making in a few hands, pre-empts an undergrowth of competing demands, gets on with self-perceived priorities more or less unhobbled by political or social pulls and pressures. It is able for the duration of its supremacy to enforce two of the preconditions of growth - stability and efficiency. But there are also problems. 
First, authoritarian rule does not usually provide for an easy transition, and even more rarely for one able or oriented to taking its economic work forward. There is rarely in history and example of such a category of a do-gooder being succeeded by his like.

Secondly, a forced pace of growth is necessarily flawed in distributive justice. It spawns anomalies and inequalities. In Indonesia it created a closely linked patronage structure of the president's family members and associates. In Malaysia it may have caused the emergence of an ethnic Malaysian middle class, which further strengthened the power structure, but it has left the ethnic Chinese half of the population feeling unfairly done by.

Thirdly, it is more prone to adoption, and less fitted for timely correction, of insufficiently considered macroeconomic policies and methods, such as have seen last year's sudden massive meltdown in East Asia.

Fourthly, it engenders a pressure-cooker effect. Failures in distributive justice add to the accumulation of resentment at the denial of freedoms. A critical mass is sooner or later reached and human waves then surge against the instruments of repression. That is what happened in south Korea in the late 80 s and is happening now in Indonesia.

Finally, it forecloses the development of institutions and mechanisms for the testing of contrary opinions, reaching of compromises, honing of decisions, and development of wider consensuses and acceptability. By limiting participation in decision-making it smothers the process of political growth.

In sum, if authoritarianism is efficient it is also prone to accidents. Its rigidity prevents its ability to absorb shocks. It either reacts strongly or it breaks. And it is usually deficient in the mode of continuity, if not in a desire for self-perpetuation.

Also, for each authoritarian government that has produced economic results there have been scores that have not. As The Economist once wrote, "If authoritarianism made countries rich Africa today would be an economic colossus." Conversely, if several developing countries in South Asia and the South Pacific have economically lagged behind, it is not because they have held periodic elections and permitted varying measures of freedom to their people. It is basically because they have not done these genuinely and extensively enough. 
The point of democracy is that people have a feeling of participation, of being more or less in control. And freedom also of course means freedom from want.

It is admitted that this is not possible of being achieved in a hurry in developing societies. But it is not impossible either that there is movement in this direction, and that movement is open, unmistakable and emphatic.

The failure of democracy in most developing countries is, first, that it does not go to the vital grass root level where the community gets the opportunity freely to organise itself, to identify its local needs, and to set about implementing its priorities.

Secondly, the elections that are held do not remotely fulfil their purpose because of the role played both by the political parties and the state. It ensures that mostly only the rich and/or the influential get elected; in other words, those that have a strong stake in the status quo. Large sections of the people, those in whom democracy if it has to have any meaning should be grounded, go altogether unrepresented. The 'representatives' are in effect pre-selected, and the voters are virtually offered a non-choice.

Thirdly, the government that gets formed in this way is a concentrate of the characteristics of these pre-selected people. So is the opposition, because it also emerges from the same process and the same milieu. So whether the government endures or alternates power with the opposition, the rule by an unreconstructed polyarchy continues.

To compare the economic performance of such a sanctified 'democracy' with an autocracy that has continually to justify its repression, which has to seek its sanction in what it delivers in material terms over a limited period, is to make a wrongful comparison; it is to miss the essential variables between the two.

The assumption that new democracies tend to be unstable and inefficient derives from current examples of democracies. If these democracies strove to be more of what they claim - that is, if the rules of governance devised have embedded within them a system of popular participation, consultation and control, transparency and accountability, and strong enough guarantees of the fundamental rights of the people - this is bound to promote the stability that matters, stability of the system itself and the possibility of its continuous self-improvement. Stability, anyhow, does not necessarily mean stability of the government in power. 
Government is just one arm of the state, and it does not have to be such a predominant and all-important arm as in most current democracies.

Inefficiency is also nursed most by lack of transparency and accountability and by the distance between the rulers and the ruled. It is not so much an attribute of democracy as a measure of its absence.

These requisites may sound utopian. They are so only because the interests they will strike at are powerful and entrenched, though small. But the challenges the developing countries have ahead of them, especially in face of the marauding aspects of globalisation,' will make the status quo of either kind increasingly untenable. The advantages of the past especially created to nurse and nourish the so-called Asian Tigers are already becoming unthinkable. Democratic economic choice, it is now recognised, will be essential to introduce development from below. And democratic political and social choice will be vital for the expansion of human freedom and capabilities. Not only has economic growth to be maximised, it will have to be equitably distributed and brought within the critical scrutiny of the people themselves. Command societies now are even more liable to fail in the longer run than command economies. ${ }^{6}$

The dichotomy seen between human rights and economic development, or between the two categories of human rights, is in any other than the short term false and likely in the future to do a society irreparable damage.

\footnotetext{
${ }^{5}$ See, for instance, UNDP, Human Development Report 1997. Chapter on Globalisation.

${ }^{6}$ See Louis Emmenj (Ed.), Economic and Social Development into the XXI Century; Hamish McRae, The World in 2020, Power, Culture and prosperity: A vision of the Future.
} 
The Labore Journal of Economics, Vol.3, No.1

\section{References}

Emmenj Louis (Ed), 'Economic and social Development, into the XXI Century;' in The World in 2020, Power, Culture and prosperity: A Vision of the Future, Hamish McRae.

Lipset, Seymour Martin, 1959 Political Man: The Social Bases of Politics, 1959.

Some Social Requisites of Democracy: Economic Development and Political Legitmacy, American Political Science Review, March 1959.

UNDP, Human Development Report 1997. 